\title{
Pemanfaatan Instagram Live sebagai Sarana Edukasi Kesehatan Masyarakat di masa Pandemi COVID-19
}

\author{
${ }^{1}$ Chahya Kharin Herbawani, ${ }^{2}$ Zefanya Geraldine Ruthin, ${ }^{3}$ Luthfiya Ramadhania, \\ ${ }^{4}$ Ayu Magdalena Natalia Situmeang, ${ }^{5}$ Ulya Qoulan Karima \\ 1,2,4,5 Program Studi Kesehatan Masyarakat, UPN Veteran Jakarta \\ ${ }^{3}$ Prodi Studi Kesehatan Masyarakat, UIN Syarif Hidayatullah Jakarta \\ Email: chahyakharin@upnvj.ac.id
}

\section{Article Info}

Submitted: 5 September 2020

Revised: 26 November 2020

Accepted: 30 December 2020

Published: 21 April 2021

Keywords: Education, community, COVID-19, Social Media
Kata kunci: Edukasi, COVID-19, Media Sosial, Masyarakat

\begin{abstract}
Since the first detection of Corona Virus Disease 2019 (COVID-19) case in Indonesia in early March 2020, the spread of COVID-19 in Indonesia has widened. One of the reason is because of Large-Scale Social Restrictions or in Indonesia we know it as Pembatasan Sosial Berskala Besar (PSBB). Considering the impact on other aspects, especially in the economy, the government considered new policies by loosening the PSBB, so that we entered a period called the New Normal. The aim of this program is to educate the community regarding COVID-19 and New Normal during the COVID-19 pandemic. Education is carried out in the form of a talk show using the live instragram feature for 60 minutes. An assessment of measure a knowledge was carried out after the material presentation session consisting of 14 questions via an online questionnaire. A total of 68 out of 110 participants completed this questionnaire. In general, the participants knowledge after the material presentation was good with a score of $78.8 \%$. Based on the percentage of participants correct answers, half of the participants were in the good knowlede, and 44\% of the participants were in the very good knowledge category. Participants with a good knowledge are expected to be able to spread their understanding of the New Normal to their relatives or their surroundings Instagram live can be a solution to give education to community. The limitation of this study is that not all people are familiar with Instagram.
\end{abstract}

Abstrak
Sejak temuan kasus Corona Virus Disease 2019 (COVID-19) pertama di
Indonesia pada awal Maret 2020, penyebaran COVID-19 di Indonesia
semakin meluas, sehingga dikeluarkan kebijakan tentang Pembatasan
Sosial Berskala Besar (PSBB). Agar aspek kehidupan lainnya
terutama dalam ekonomi dapat tetap berjalan, pemerintah kemudian
mempertimbangkan kebijakan baru dengan melonggarkan PSBB,
sehingga kita memasuki masa yang disebut New Normal. Tujuan dari


program ini adalah untuk mengedukasi masyarakat terkait COVID-19 dan New Normal di masa pandemi COVID-19. Edukasi dilakukan dalam bentuk talkshow dengan menggunakan fitur live instagram selama 60 menit. Penilaian terhadap pemahaman dilakukan setelah sesi pemaparan materi yang terdiri dari 14 pertanyaan melaui kuesioner online. Sebanyak 68 dari 110 peserta, melengkapi kuesioner ini. Secara umum, pemahaman peserta setelah materi dapat dikatakan baik dengan skor nilai sebesar 78,8\%. Berdasarkan persentase jawaban benar masing-masing peserta, setengah dari peserta termasuk dalam kategori pemahaman baik, dan $44 \%$ peserta termasuk dalam kategori pemahaman sangat baik. Peserta dengan pemahaman yang baik diharapkan mampu menyebarluaskan pemahamannya mengenai New Normal ke kerabat atau lingkungan sekitarnya. Instagram live dapat menjadi salah satu solusi media edukasi yang mudah dan murah untuk diakses oleh masyarakat. Keterbatasan penelitian ini adalah tidak seluruh masyarakat familiar dengan media sosial Instagram Live.

\section{PENDAHULUAN}

COVID-19 menjadi perhatian serius dalam kesehatan masyarakat setelah dinyatakan sebagai pandemi. Kasus pertama COVID-19 dilaporkan terjadi di Wuhan pada tahun 2019. Pada awalnya WHO menyebut penyakit ini dengan nama Novel Coronavirus 2019 atau 2019-nCoV (Pradana, Casman, \& Nur'aini, 2020). Kemudian pada tanggal 11 Februari 2020, WHO mengumumkan secara resmi COVID-19 sebagai penyakit yang disebabkan oleh Severe Acute Respiratory Syndrome Coronavirus-2 (SARS$\mathrm{CoV}$-2). Virus tersebut menginfeksi dan merusak jaringan yang berada dalam saluran napas manusia (Atmojo, Akbar, \& Kuntari, 2020). Berdasarkan data yang dihimpun dari laman WHO, hingga tanggal 24 Juli 2020 dilaporkan sebanyak 15.257.287 kasus terkonfirmasi dan menyebabkan 628.240 kematian akibat COVID-19 di dunia (WHO, 2020).

Sedangkan di Indonesia, sejak temuan kasus Corona Virus Disease 2019 (COVID-19) pertama di Indonesia yang disampaikan langsung oleh Presiden Joko Widodo pada tanggal 2 Maret 2020, penyebaran COVID-19 di Indonesia semakin meluas. Jumlah kasus dan jumlah kematian telah meningkat dan meluas lintas daerah. Peningkatan ini selain berdampak pada aspek kesehatan, juga berdampak pada banyak aspek kehidupan lainnya termasuk politik, ekonomi, sosial, budaya, pertahanan, dan keamanan, serta kesejahteraan masyarakat
Indonesia. Sampai dengan tanggal 24 Juli 2020 sebanyak 95.418 kasus konfirmasi positif dan 4.665 kematian akibat COVID-19 (Badan Nasional Penanggulangan Bencana, 2020). Jumlah tersebut masih terus mengalami peningkatan hingga saat ini.

Dalam upaya menekan penyebaran ini, pada 3 April 2020 Menteri Kesehatan RI menerbitkan Peraturan Menteri Kesehatan Nomor 9 Tahun 2020 Tentang Pedoman Pembatasan Sosial Berskala Besar (PSBB) dalam rangka percepatan penanganan COVID-19. Pembatasan Sosial Berskala Besar (PSBB) adalah pembatasan kegiatan tertentu penduduk dalam suatu wilayah yang diduga terinfeksi COVID-19 sedemikian rupa untuk mencegah kemungkinan penyebaran COVID-19 (PMK No. 9 Tahun 2020). Sejak dikeluarkannya peraturan tersebut, telah berjalan beberapa seri PSBB di beberapa provinsi di Indonesia sejak pertengahan April 2020.

PSBB diterapkan pertama kali di Provinsi Daerah Khusus Ibukota (DKI) Jakarta pada tanggal 10 April 2020 di mana Jakarta merupakan episentrum wabah COVID-19 di Indonesia. Jakarta sendiri bersama beberapa kabupaten dan kota di Indonesia sudah melakukan kebijakan darurat wabah COVID-19 secara lokal dengan memberlakukan libur sekolah untuk sekolah negeri dan himbauan untuk sekolah swasta, pembatasan transportasi umum milik Pemda, menutup tempat wisata 
milik Pemda, menghimbau agar kantor-kantor baik pemerintah pusat maupun swasta agar melakukan pekerjaan di rumah (work from home), dan beberapa kebijakan lain yang masih merupakan lingkup kewenangan pemerintah daerah (Muhyiddin, 2020).

Pelaksanaan PSBB yang efektif, diharapkan dapat berdampak positif terhadap penurunan kasus COVID-19. Namun disamping itu, pemerintah juga memikirkan agar aspek kehidupan lainnya terutama dalam ekonomi dapat tetap berjalan, maka pemerintah kemudian mempertimbangkan kebijakan baru dengan melonggarkan PSBB dan mencanangkan masa New Normal. Beberapa penelitian menjelaskan, suatu kebiasaan yang terus-menerus dilakukan akan menjadi kebiasaan baru. Untuk hal ini, hampir semua peneliti sosial duduk dalam pendapat yang sama. Perbedaannya terletak berapa lama kebiasaan baru itu terbentuk (Habibi, 2020).

Enam kriteria yang ditentukan oleh World Health Organization (WHO) pada 13 April 2020 untuk dapat melonggarkan PSBB diantaranya adalah transmisi atau penularan COVID-19 dapat dikendalikan, kapasitas sistem pelayanan kesehatan mampu mendeteksi, melakukan tes/ uji laboratorium, mengisolasi, dan mengobati setiap kasus dan melacak orang-orang yang kontak dengan kasus, mengurangi risiko wabah dengan peraturan ketat pada populasi dengan keretanan tinggi, tindakan pencegahan dilakukan di tempat-tempat umum seperti kantor/tempat kerja, sekolah, dll, risiko kasus impor dapat dikelola, serta masyarakat teredukasi, terlibat, dan berdaya untuk menyesuaikan diri dengan situasi New Normal (WHO, 2020b).

Pelonggaran PSBB harus disertai dengan kesiapan dalam beradaptasi melalui perubahan pola hidup pada situasi COVID-19 atau yang lebih dikenal dengan konsep New Normal. Transisi menuju New Normal harus disertai dengan prinsip-prinsip kesehatan masyarakat seiring dengan pertimbangan ekonomi dan social (Kemenkes RI, 2020). Salah satu peraturan yang dikeluarkan terkait adaptasi New Normal ini adalah Keputusan Menteri Kesehatan RI, No. HK. 01.07/Menkes/328/2020 pada tanggal 20 Mei 2020 tentang Panduan Pencegahan dan Pengendalian COVID-19 di Tempat Kerja
Perkantoran dan Industri dalam Mendukung Keberlangsungan Usaha Pada Situasi Pandemi.

Secara umum, data dari Satuan Tugas Penanganan COVID-19 menunjukkan tren peningkatan kasus terkonfirmasi positif walau sudah diberlakukannya kebijakan New Normal sejak 1 Juni 2020. Pengetahuan sangat penting dalam membentuk aspek sikap dan perilaku seseorang. Pengetahuan masyarakat dalam beradaptasi di masa New Normal akan menekan penularan COVID-19 apabila diikuti oleh perilaku yang sesuai. Kebijakan New Normal sudah diterapkan, namun dapat dilihat banyak masyarakat Indonesia yang belum mengerti sepenuhnya mengenai kebijakan New Normal ini.

Kebutuhan akan informasi yang akurat, tepat, dan terkini semakin dibutuhkan seiring dengan perkembangan teknologi informasi yang sangat pesat (Leonita \& Jalinus, 2018). Data dari penelitian yang dilakukan oleh Utami, dkk yang dilakukan dengan kuesioner online tentang pengetahuan, sikap, dan keterampilan masyarakat dalam pencegahan COVID-19 di Provinsi DKI Jakarta menunjukkan bahwa 83\% responden memiliki pengetahuan baik, 70,7\% sikap yang baik, dan 70,3\% keterampilan yang baik dalam pencegahan COVID-19. Adapun aspek pengetahuan yang ditanyakan adalah mengenai proses penularan penyakit, pencegahan yang dapat dilakukan, dan informasi sebaran kasus. Secara umum mayoritas pengetahuan, sikap, dan keterampilan masyarakat Provinsi DKI Jakarta baik dalam pencegahan COVID-19. Namun demikian upaya untuk terus mengedukasi masyarakat tetap harus dilakukan terutama karena informasi-informasi yang selalu update di setiap tahap perkembangan kondisi COVID-19 dengan memanfaatkan berbagai sosial media yang ada untuk tetap menjaga protokol kesehatan (Utami, Mose, \& Martini, 2020).

Saat masa pandemi COVID-19, pemanfaatan internet sebagai media dalam menjalin hubungan sosial semakin menjadi pilihan, karena dibatasinya ruang bertemu di dunia nyata demi menjaga protokol kesehatan. Media sosial melalui internet memiliki potensi besar untuk melakukan promosi kesehatan dan intervensi kesehatan lainnya, dan lebih mudah untuk menyentuh sasaran pada setiap levelnya (Leonita 
\& Jalinus, 2018). Dari 10 sosial media, pengguna instagram menempati posisi ke-4 sebagai media sosial yang sering digunakan di Indonesia setelah Youtube, WhatsApp, dan Facebook ("Media Sosial Yang Paling Sering Digunakan Di Indonesia," n.d.). Instagram juga dipilih karena merupakan media yang relatif mudah digunakan baik bagi penyelenggara maupun peserta.

Pelaksanaan kegiatan menggunakan media instagram live agar mudah dijangkau oleh masyarakat dan sebagai media platform yang kebanyakan digunakan oleh masyarakat. Selain itu, berdasarkan laporan dari NapoleonCat, jumlah pengguna aktif bulanan Instagram di Indonesia dilaporkan telah mencapai 61.610.000 atau sekitar 22,6 total penduduk Indonesia. Pengguna instagram berusia 18-24 tahun menjadi kelompok usia pengguna paling besar di Indonesia, dengan total persentase 37,3 persen atau sekitar 23 juta pengguna (KOMINFO RI, n.d.). Sehingga tujuan dari program ini adalah untuk mengedukasi masyarakat terkait COVID-19 dan New Normal di masa pandemi COVID-19 dengan cara seefektif dan efisien mungkin, yakni melalui salah satu platform media sosial Instagram dengan harapan dapat menjangkau lebih banyak orang dan dari kalangan masyarakan yang beragam.

\section{METODE}

Pelaksanaan talkshow diadakan oleh Program Studi Kesehatan Masyarakat UPN VeteranJakartabekerja sama dengan Departemen Pengabdian dan Pengembangan Masyarakat, Pergerakan Anggota Muda Ikatan Ahli Kesehatan Masyarakat Indonesia (IAKMI) atau disingkat sebagai PAMI Jakarta Raya. Dalam melaksanakan persiapan terkait talkshow ini, pertama-tama dilakukan analisis situasi masalah terlebih dahulu dengan mempertimbangkan berbagai hal. Hal pertama yang menjadi pertimbangan dalam analisis situasi adalah penelusuran isu kesehatan yang sedang ramai diperbincangkan di berbagai media, lalu hal kedua adalah penelusuran kepustakaan terkait data dan fakta isu kesehatan tersebut. Setelah dilakukan analisis situasi masalah, maka didapatkan isu pengabdian masyarakat yang diharapkan sesuai dengan kebutuhan masyarakat, yakni terkait COVID-19 dan New Normal.
Analisis situasimasalah

Penentuan tema, waktu dan platform yang sesuai

Publikasi kegiatan di berbagai sosial media

Pelaksanaan kegiatan Talkshow di Instagram Live

\section{Pemberitahuan link evaluasi}

Gambar 1, Diagram alur perisapan, pelaksanaan dan evaluasi pemanfaatan Instagram Live sebagai sarana Edukasi Masyarakat terkait COVID-19 di masa Pandemi COVID-19

New Normal diputuskan menjadi tema talkshow dikarenakan hasil analisis situasi masalah menunjukkan bahwa masyarakat saat ini masih banyak yang belum memahami tentang kebijakan new normal atau kebiasaan hidup baru. Hal ini ditunjukkan dengan masih ada masyarakat yang memahami bahwa kebijakan new normal adalah kembali hidup normal seperti biasanya, padahal kehidupan normal itu berati kita harus membiasakan dalam menjalani protokol kesehatan di berbagai tatanan untuk memutus mata rantai penularan COVID-19. Setelah didapatkan isu kesehatan yang sesuai, langkah selanjutnya yakni menentukan tema.

Tema yang disepakati pada kegiatan pengabdian masyarakat ini yaitu "New Normal = Kembali Hidup Normal?". Kegiatan Talkshow Seputar COVID-19: New Normal ini dilakukan dengan tujuan untuk meningkatkan tingkat pemahaman dan kesadaran masyarakat mengenai New Normal. Sehingga secara tidak langsung masyarakat dapat ikut berperan dalam menurunkan jumlah kasus positif COVID-19 dengan melakukan perilaku pencegahan COVID-19.

Pelaksanaan kegiatan ini diadakan dengan menggunakaan akun sosial media PAMI Jakarta Rayayaitu fitur IGTV (instagram). Akun instagram PAMI Jakarta Raya memiliki 1.084 followers yang menjadi sasaran strategis talkshow ini. Tidak hanya mahasiswa kesehatan masyarakat saja, namun seluruh masyarakat pun dapat mengikutinya. Beberapa hari sebelum talkshow, dilakukan publikasi acara melalui berbagai sosial media. Waktu pelaksanaan pada malam hari 
dengan pertimbangan bahwa berdasarkan data peak hour pengguna sosial media di Indonesia adalah pada pukul 07.00 WIB dan 18.00 WIB. Selain itu, wajtu pelaksanaan talkshow juga pertimbangan bahwa masyarakat telah selesai dengan kegiatan dan aktivitas pada pagi/siang hari, sehingga dapat relatif lebih mudah untuk bergabung dan mengikuti talkshow juga menjadi pertimbangan dalam waktu penyelenggaran talkshow.

Pelaksanaan talkshow dimulai dari pembukaan oleh moderator, pemaparan materi oleh narasumber dan dilanjutkan oleh sesi diskusi dengan mejawab pertanyaan-pertanyaan dari audiens terkait new normal. Acara berjalan dengan lancar yang dimulai pukul 19.30-20.30 WIB. Materi talkshow secara garis besar dibagi menjadi sub-topik besar yaitu data terbaru tentang COVID-19, sejarah new normal, konsep New Normal, syarat dan protokol kesehatan pada saat New Normal, dan hal-hal lain terkait COVID-19.

Jumlah peserta yang mengikuti live instagram sebanyak 110 orang. Antusiasme pesertaterlihat dari cukup banyaknya pertanyaan yang diajukan yaitu sebanyak 20 pertanyaan. Beberapa pertanyaan yang masuk adalah seperti tanggapan terkait pemahaman dan penerapan new normal di Indonesia dewasa ini, apakah kebijakan new normal sebaiknya dilanjutkan, tanggapan terkait dibukanya kembali mall dengan protokol kesehatan, bagaimana kesiapan masyarakat terkait new normal, dll.

Dalam pengabdian kesehatan masyarakat ini terdapat beberapa kendala yang dihadapi. Kendala utama yang dialami baik oleh narasumber maupun peserta ialah berupa kendala jaringan yang tidak selalu stabil. Selain itu, keterbatasan dari pelaksanaan pengabdian masyarakat ini adalah target sasaran peserta tidak dapat menjangkau seluruh kalangan masyarakat, karena sebagian besar pengguna instagram adalah kalangan usia muda.

Setelah live instagram berlangsung, terdapat evaluasi berupa survey yang terdiri dari beberapa pertanyaan seputar topik COVID-19 dan New Normal berkaitan dari materi talkshow yang telah disampaikan pada live instagram . Pertanyaan evaluasi terdiri dari 7 soal pilihan ganda dan 7 pertanyaan benar-salah untuk mengetahui dan mengukur pemahaman peserta tentang isi materi.

Survey diisi oleh peserta setelah peserta mendengarkan materi, lalu dilakukan juga pengolahan data berdasarkan jawaban-jawaban dari survey tersebut. Pertaanyaan evaluasi dalam survey ialah terkait istilah 'New Normal' pertama kali muncul, syarat New Normal, barang-barang yang harus dibawa di era New Normal, kegiatan yang memiliki risiko tinggi saat pandemi COVID-19, penggunaan face shield, dll.

\section{HASIL DAN PEMBAHASAN}

Peserta yang mengikuti talkshow sebanyak 110 orang, namun yang mengisi kuesioner sebayak 68 orang. Adapun karakteristik peserta adalah sebagai berikut

Tabel 1. Distribusi Frekuensi Karakteristik Sosial Demografi

\begin{tabular}{lcc}
\hline \multirow{2}{*}{ Sosial Demografi } & \multicolumn{2}{c}{ Jumlah (68) } \\
\cline { 2 - 3 } & $\mathbf{N}$ & $\mathbf{9}$ \\
\hline Umur & 4 & 5,9 \\
$<18$ Tahun & 55 & 80,9 \\
18-21 Tahun & 9 & 13,2 \\
$>$ 21 Tahun & 20,28 & $(2,76)$ \\
Mean (SD) & 20,00 & $(15-38)$ \\
Median (Range) & & \\
\hline Jenis Kelamin & 7 & 10,3 \\
Laki-laki & 61 & 89,7 \\
Perempuan & & \\
Pendidikan & \\
SMA & 19 & 28,4 \\
D3 & 2 & 3,0 \\
D4 & 1 & 1,5 \\
S1 & 45 & 67,2 \\
\hline Provinsi & & \\
Banten & 15 & 22,1 \\
DIY & 1 & 1,5 \\
DKI Jakarta & 17 & 25,0 \\
Jawa Barat & 23 & 33,8 \\
Jawa Tengah & 4 & 5,9 \\
Jawa Timur & 1 & 1,5 \\
Kalimantan Timur & 1 & 1,5 \\
Lampung & 1 & 1,5 \\
Riau & 1 & 1,5 \\
Sulawesi Selatan & 1 & 1,5 \\
Sumatera Utara & 2 & 2,9 \\
& &
\end{tabular}


Sumatera Barat

1

1,5

a Missing 1

Berdasarkan Tabel 1, terlihat bahwa dari segi umur, sebagian besar peserta berumur 18-21 tahun (80,9\%). Umur terendah adalah 15 tahun, sementara umur tertinggi adalah 38 tahun. Dari segi jenis kelamin, mayoritas peserta adalah perempuan $(89,7 \%)$. Hal ini sesuai dengan penelitian (Prihatiningsih, 2017) yang memperlihatkan bahwa informan penelitian yakni remaja, memiliki kebutuhan dalam menggunakan instagram baik dari kebutuhan kognitif, kebutuhan afektif, kebutuhan integrasi personal, kebutuhan integrasi sosial, dan kebutuhan berkhayal atau hiburan. Instagram ternyata dapat menambah pengetuan remaja mengenai dunia. Dengan menggunakan instagram, kebutuhan kognitif penggunanya sedikit banyak terpenuhi. Keingintahuan pengguna atas beragam hal dapat terpenuhi dengan melihat konten-konten yang ada di dalamnya (Prihatiningsih, 2017).

Tingkat pemahaman masyarakat khususnya pada peserta kegiatan tersebut dapat diukur secara objektif dalam bentuk kuesioner berisikan beberapa pertanyaan. Jumlah keseluruhan pertanyaan dalam kuesioner tersebut adalah 14 butir soal, yang terdiri dari 7 soal bentuk pilihan ganda dan 7 soal bentuk pilihan benar dan salah. Untuk melihat tingkat pemahaman peserta, teknik pengolahan data yang digunakan dalam penelitian ini adalah berdasarkan:

1. Jumlah poin jawaban benar (rentang nilai 0-14 poin)

Tabel 2. Distribusi Frekuensi Jumlah Poin Jawaban Benar

\begin{tabular}{ccc}
\hline $\begin{array}{c}\text { Jumlah Poin } \\
\text { Jawaban Benar }\end{array}$ & \multicolumn{2}{c}{ Jumlah (68) } \\
$\mathbf{N}$ & $\mathbf{\%}$ \\
\hline 7 & 1 & 1,5 \\
8 & 3 & 4,4 \\
9 & 9 & 13,2 \\
10 & 11 & 16,2 \\
11 & 14 & 20,6 \\
12 & 19 & 27,9 \\
13 & 8 & 11,8 \\
14 & 3 & 4,4
\end{tabular}

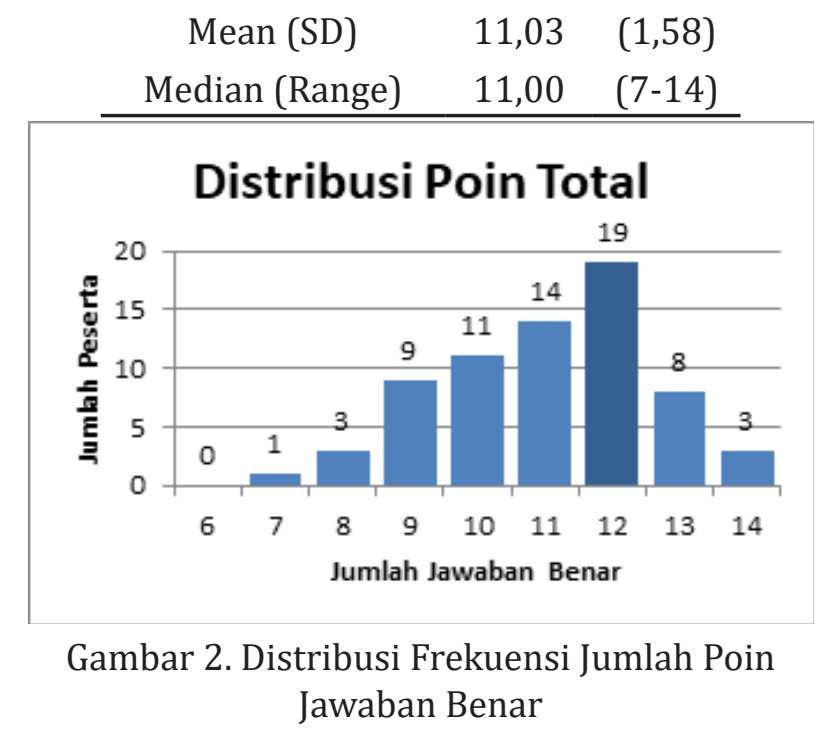

Jumlah seluruh peserta yang telah mengisi kuesioner sebanyak 68 orang. Total jumlah poin jawaban benar yang telah didapatkan dari seluruh peserta ialah sebesar 750 poin. Seperti pada gambar 1, dapat dilihat bahwa jumlah poin jawaban benar terendah yang didapatkan sebesar 7 poin ialah sebanyak 1 orang $(1,5 \%)$, jumlah poin jawaban benar tertinggi yang didapatkan sebesar 14 poin ialah sebanyak 3 orang $(4,4 \%)$, dan jumlah poin jawaban benar terbanyak sebesar 12 poin ialah sebanyak 19 orang $(27,9 \%)$. Berdasarkan hasil olah data kuesioner tersebut, didapatkan rata-rata poin jawaban benar responden sebesar 11,03 poin $(S D=$ 1,58), nilai tengah (median) sebesar 11 poin dan dengan rentang nilai antara 7-14 poin.

2. Konversi total poin jawaban benar dari seluruh peserta ke dalam persentase

Total jumlah poin yang telah didapatkan dari seluruh peserta ialah sebesar 750 poin. Sementara total jumlah poin maksimal yang bisa didapatkan jika semua jawaban peserta benar adalah sebesar 14 poin dikali 68 peserta yaitu sebesar 952 poin. Angka presentase dapat diperoleh dengan menggunakan rumus sederhana, yaitu:

(Rumus 1)

$$
\begin{aligned}
& \Sigma \text { poin yang diperoleh } \\
& \text { Persentase }=\frac{\text { seluruh peserta }}{\begin{array}{l}
\Sigma \text { poin maksimal } \\
\text { seluruh peserta jika } \\
\text { semua jawaban benar }
\end{array}} \times 100 \%
\end{aligned}
$$

Warta LPM, Vol. 24, No. 2, April 2021 
Dengan interpretasi kriteria pemahaman sebagai berikut:

Tabel 3. Kriteria Pemahaman

\begin{tabular}{cc}
\hline Persentase & Kriteria Pemahaman \\
\hline $81-100 \%$ & Sangat Baik \\
$61-80 \%$ & Baik \\
$41-60 \%$ & Cukup \\
$21-40 \%$ & Kurang \\
$0-20 \%$ & Sangat Kurang \\
\hline \multicolumn{2}{c}{ Sumber: Evitasari, 2013 }
\end{tabular}

Hasil perhitungannya adalah sebagai berikut:

$$
\begin{aligned}
& (1 \times 7)+(3 \times 8)+(9 \times 9) \\
& +(11 \times 10)+(14 \times 11) \\
& \text { Persentase }=\frac{+(19 \times 12)+(8 \times 13)+(3 \times 14)}{68 \times 14} \times 100 \% \\
& =\frac{750}{952} \times 100 \% \\
& =78,8 \%
\end{aligned}
$$

Berdasarkan hasil perhitungan, didapatkan bahwa presentase poin jawaban benar dari seluruh peserta ialah sebesar $\mathbf{7 8 , 8 \%}$. Hal tersebut dapat diartikan bahwa tingkat pemahaman peserta mengenai $\mathrm{New}$ Normal dalam kategori baik. Diharapkan peserta mampu menyebarluaskan pemahamannya mengenai New Normal ke dalam kerabat atau lingkungan sekitarnya.

Berdasarkan hasil data kuesioner, sebanyak 37 orang $(50,7 \%)$ menyatakan bahwa tingkat keefektifan intervensi dan edukasi dalam kegiatan tersebut menurut responden terbilang cukup efektif. Hal tersebut sesuai dengan penelitian (Yulia, 2018) yang menyebutkan bahwa penggunaan media sosial dapat menjadi salah satu strategi yang dapat digunakan oleh promotor kesehatan demi tercapainya tujuan kesehatan masyarakat. Selain memiliki jangkauan yang luas, media sosial juga berbiaya rendah apabila dibandingkan dengan media konvensional.

3. Persentase jawaban benar masing-masing peserta

Tabel 4. Distribusi Frekuensi Persentase Jawaban Benar Peserta

\begin{tabular}{ccc}
\hline $\begin{array}{c}\text { Persentase Jawaban } \\
\text { Benar }\end{array}$ & \multicolumn{2}{c}{ Jumlah (68) } \\
N & \% \\
\hline $41-60 \%$ (Cukup) & 4 & 5,9 \\
61-80\% (Baik) & 34 & 50,0 \\
81-100\% (Sangat Baik & 30 & 44,1 \\
Mean (SD) & 78,78 & $(11,32)$ \\
Median (Range) & 78,60 & $(50,0-100,0)$ \\
\hline
\end{tabular}

Berdasarkan Tabel 4, setengah dari peserta termasuk dalam kategori pemahaman baik, dan $44 \%$ peserta termasuk dalam kategori pemahaman sangat baik. Walaupun demikian, masih terdapat 5,9\% peserta dengan kategori pengetahuan cukup, dengan persentase nilai terendah sebesar $50 \%$. Kelompok ini meski proporsinya paling kecil, namun perlu diperhatikan untuk menjadi evaluasi pelaksanaan kegiatan.

Hasil penelitian (Fatimah \& Indrawati, 2020) menunjukkan bahwa pengetahuan berpengaruh terhadap sikap dan tindakan individu sebagai usaha pencegahan COVID-19. Selain itu, Berdasarkan hasil penelitian (Sari, Sholihah, \& Atiqoh, 2020) juga menyimpulkan bahwa terdapat hubungan antara pengetahuan masyarakat dengan kepatuhan menggunakan masker sebagai upaya pencegahan penyakit COVID-19. Sehingga diharapkan dengan pemberian pengetahuan yang spesifik, valid, dan tepat sasaran dapat meningkatkan perilaku usaha pencegahan masyarakat terhadap infeksi COVID-19.

4. Persentase jawaban benar setiap pertanyaan 
Tabel 5. Proporsi Jawaban Benar Antara Sebelum dan Sesudah Penyuluhan

\begin{tabular}{llcc}
\hline \multirow{2}{*}{ No } & \multicolumn{1}{c}{ Pertanyaan } & \multicolumn{2}{c}{ Jawaban Benar } \\
& & n & \% \\
\hline & Pilihan Ganda & 49 & 72,0 \\
1 & Istilah New Normal pertama kali mengacu pada & 57 & 83,8 \\
2 & Syarat New Normal berjalan baik & 63 & 92,6 \\
3 & Barang yang harus dibawa saat New Normal & 67 & 98,5 \\
4 & Sisi positif pandemi COVID-19 & 15 & 22,0 \\
5 & Awal ditetapkannya New Normal & 45 & 66,2 \\
6 & Syarat WHO untuk menerapkan New Normal & 65 & 95,6 \\
7 & Kegiatan yang tidak berisiko saat pandemi COVID-19 & & \\
\hline & Pertanyaan Benar/Salah & 62 & 91,2 \\
1 & Penggunaan face shield sudah cukup & 60 & 88,2 \\
2 & Syarat WHO berupa kelola kasus impor & 47 & 69,1 \\
3 & Kesesuaian penerapan New Normal di Indonesia & 12 & 17,6 \\
4 & Syarat WHO berupa penurunan kasus COVID-19 & 68 & 100,0 \\
5 & Gangguan psikososial akibat penerapan lockdown & 64 & 94,1 \\
6 & Peran epidemiologi berupa sajian data COVID-19 & 64 & 100,0 \\
\hline 7 & Belanja ke mal termasuk kegiatan risiko rendah & &
\end{tabular}

Berdasarkan Tabel 5, terlihat bahwa 2 pertanyaan dengan jawaban benar yang paling rendah yaitu pertanyaan tentang awal mula diterapkannya new normal pada saat pandemi COVID-19 (hanya 22\% yang menjawab secara benar) dan pertanyaan tentang apakah grafik kasus COVID-19 yang menunjukkan penurunan merupakan syarat penerapan new normal dari WHO (hanya $17,6 \%$ yang menjawab secara benar). Hal ini dapat terjadi karena tidak semua lapisan masyarakat memahami dengan benar makna dari istilah "new normal" di masa pandemi COVID-19.

5. Hubungan Faktor Sosial Demografi dengan Tingkat Pengetahuan

Berdasarkan Tabel. 6, terlihat bahwa umur $>20$ tahun mempunyai kecenderungan 1,42 kali (95\% CI: 0,51-3,95) untuk mendapatkan nilai di atas median. Namun hubungan ini tidak bermakna secara statistik ( $p$ value $=0,604)$. Namun bila dilihat dari tingkat pendidikan, justru pendidikan S1 mempunyai kecenderungan lebih rendah untuk mendapatkan nilai di atas median $(\mathrm{OR}=0,29,95 \% \mathrm{CI}$ : 0,22$5,14)$ dibandingkan tingkat pendidikan SMA, D3, D4 dan hubungan ini bermakna secara statistik ( $p$ value $=0,034$ ). Peserta yang tinggal di DKI Jakarta mempunyai kecenderungan lebih rendah untuk mendapatkan nilai di atas median $(\mathrm{OR}=$ 0,43, 95\% CI: 0,11-1,41) dibandingkan peserta yang tinggal di luar DKI Jakarta (p value $=0,259$ ). Berdasarkan jenis kelamin, tidak ada perbedaan pengetahuan antara laki-laki dan pengetahuan. Beberapa hal perlu diperhatikan dalam memahami besaran nilai OR dan $p$ value, karena penilaian terhadap pengetahuan hanya dilakukan di setelah pemaparan materi, sehingga kita tidak dapat mengetahui kondisi pengetahuan dasar yang telah dimiliki oleh peserta. Selain itu, tidak dapat dikontrol apakah selama proses pemaparan materi, semua peserta memberikan perhatian penuh terhadap penyampaian materi. 
Herbawani, dkk - Pemanfaatan Instagram Live sebagai Sarana Edukasi ...

Tabel 6. Hubungan Faktor Sosial Demografi dengan Tingan Pengetahuan

\begin{tabular}{|c|c|c|c|c|c|c|c|}
\hline \multirow{2}{*}{ Sosial Demografi } & \multicolumn{2}{|c|}{$>$ Median } & \multicolumn{2}{|c|}{$\leq$ Median } & \multirow{2}{*}{ Total } & \multirow{2}{*}{ OR $(95 \% \mathrm{CI})$} & \multirow{2}{*}{ Nilai p } \\
\hline & $\mathbf{N}$ & $\%$ & $\mathbf{N}$ & $\%$ & & & \\
\hline \multicolumn{8}{|l|}{ Umur } \\
\hline$>20$ Tahun & 11 & 50,0 & 11 & 50.0 & 22 & $1,42(0,51-3,95)$ & 0,604 \\
\hline$\leq 20$ Tahun & 19 & 41,3 & 27 & 58.7 & 46 & 1 & \\
\hline \multicolumn{8}{|l|}{ Jenis Kelamin } \\
\hline Perempuan & 27 & 44,3 & 34 & 55,7 & 61 & $1,01(0,22-5,14)$ & 1,000 \\
\hline Laki-Laki & 3 & 42,9 & 4 & 57,1 & 7 & 1 & \\
\hline \multicolumn{8}{|l|}{ Tingkat Pendidikan } \\
\hline S1 & 15 & 33,3 & 30 & 66,7 & 45 & $0,29(0,10-0,83)$ & 0,034 \\
\hline SMA, D3, D4 & 14 & 63,6 & 8 & 36,4 & 22 & 1 & \\
\hline \multicolumn{8}{|l|}{ Provinsi } \\
\hline DKI Jakarta & 5 & 29,4 & 12 & 70,6 & 17 & $0,43(0,11-1,41)$ & 0,259 \\
\hline Luar DKI Jakarta & 25 & 49,0 & 26 & 51,0 & 51 & 1 & \\
\hline
\end{tabular}
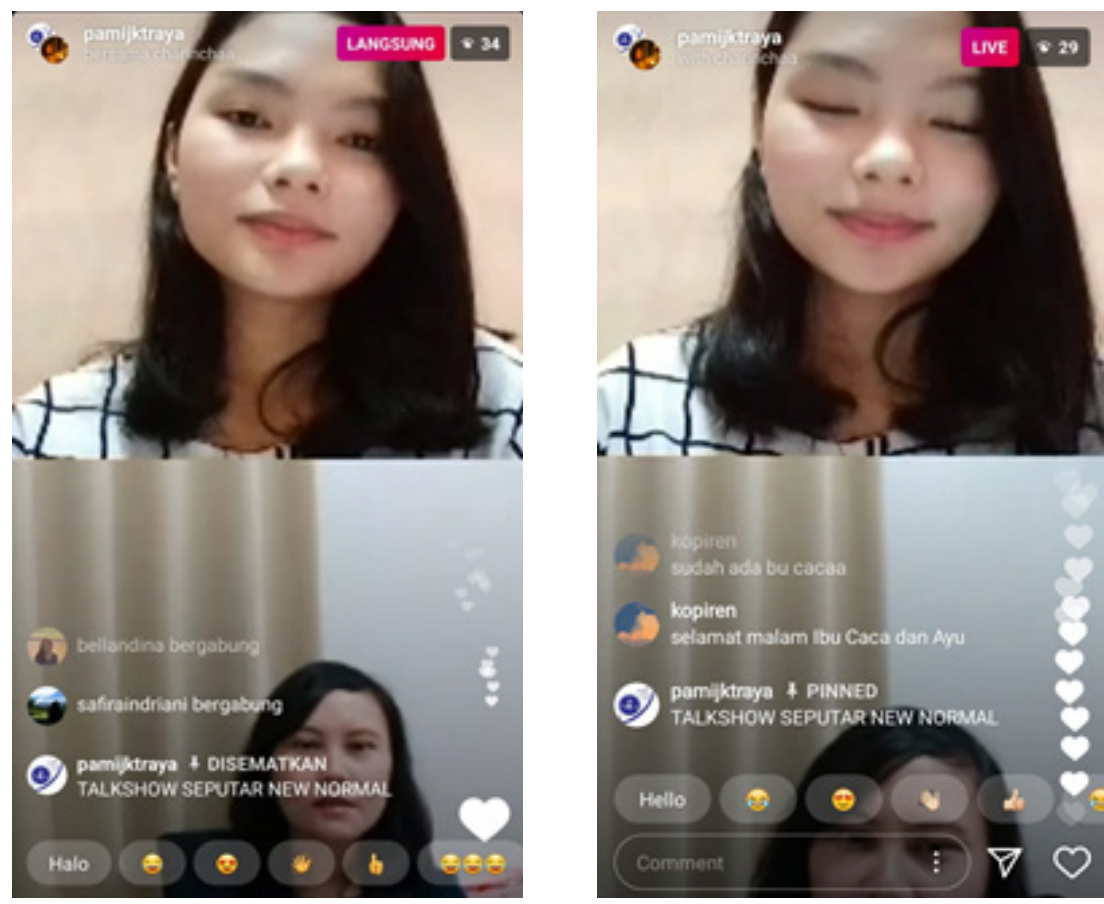

Gambar 3. Pelaksanaan Talkshow melalui Instagram Live

\section{SIMPULAN}

Sejak tanggal 11 Maret 2020, WHO (World Health Organization) telah menetapkan wabah COVID-19 sebagai pandemi tingkat global. Hal tersebut dikarenakan tingkat penyebaran COVID-19 yang sangat cepat hampir ke seluruh dunia. Indonesia, sebagai negara yang ikut terdampak wabah COVID-19 ini, menurut data yang dilansir dari laman www.covid.go.id pertanggal 22 Agustus 2020, sudah sebanyak
151. 498 kasus positif yang terkonfirmasi, 6.594 orang diantaranya meninggal dan 105.198 orang dinyatakan telah sembuh.

Dampak dari pandemi COVID-19 ini sangatlah luas, tidak hanya pada sektor kesehatan saja, tetapi juga pada sektor-sektor lain, seperti ekonomi, sosial, politik, dan lainlainnya. Pemerintah Indonesia sudah mulai menerapkan kebijakan baru dalam mengatasi dampak pandemi COVID-19, yaitu kebijakan 
new normal atau kebiasaan hidup baru untuk menanggani penyebaran COVID-19. Namun dengan angka kasus positif yang meningkat, maka dari itu perlu adanya edukasi kepada masyarakat terkait kebijakan normal baru dan anjuran mengikuti protokol kesehatan.

Berdasarkan hasil analisis data secara keseluruhan untuk pengukuran terhadap pemahaman peserta dapat disimpulkan bahwa tingkat pemahaman peserta mengenai New Normal dalam kategori baik. Selain itu, berdasarkan hasil data kuesioner, sebanyak
37 orang $(50,7 \%)$ menyatakan bahwa tingkat keefektifan intervensi dan edukasi dalam kegiatan tersebut menurut peserta terbilang cukup efektif. Sehingga, dapat disimpulkan bahwa instagram live dapat menjadi salah satu solusi sarana edukasi masyarakat terkait COVID-19 dan New Normal di masa Pandemi COVID-19. Penelitian selanjutnya disarankan dapat menggali dan memanfaatkan fitur-fitur, media sosial, dan platform digital lainnya sebagai media edukasi kesehatan di masa pandemi COVID-19.

\section{REFERENSI}

Atmojo, J. T., Akbar, P. S., \& Kuntari, S. (2020). Definisi dan Jalur Penularan Severe Acute Respiratory Syndrome Coronavirus 2 (SARS-Cov-2). Jurnal Pendidikan Kesehatan, 9(1), 57-64.

Badan Nasional Penanggulangan Bencana. (2020). No Title. Retrieved from https://covid19.go.id/ website: https://covid19.go.id/

Fatimah, S., \& Indrawati, F. (2020). Pengetahuan terkait Usaha Pencegahan Coronavirus Disease (COVID-19) di Indonesia. HIGEIA JOURNAL OF PUBLIC HEALTH RESEARCH AND DEVELOPMENT, 1(3), 84-94.

Habibi, A. (2020). Normal Baru Pasca COVID-19. 'Adalah Buletin Hukum Dan Keadilan, 4(1), 197-202. https://doi.org/10.15408/adalah.v4i1.15809.

Kemenkes RI. (2020). Keputusan Menteri Kesehatan RI No. HK. 01.07/Menkes/328/2020.

KOMINFO RI. (2019). Pengguna Internet di Indonesia 63 juta orang. Retrieved from https://www. kominfo.go.id/content/detail/3415/kominfo-pengguna-internet-di-indonesia-63-jutaorang/0/berita_satker.

Leonita, E., \& Jalinus, N. (2018). Peran Media Sosial dalam Upaya Promosi Kesehatan: Tinjauan Literatur. INVOTEK: Jurnal Inovasi Vokasional Dan Teknologi, 18(2), 25-34. https://doi.org/10.24036/ invotek.v18i2.261

Media Sosial yang Paling Sering Digunakan di Indonesia. (n.d.). Retrieved from https://databoks. katadata.co.id/datapublish/2020/02/26/10-media-sosial-yang-paling-sering-digunakan-diindonesia.

Muhyiddin. (2020). COVID-19, New Normal, dan Perencanaan Pembangunan di Indonesia. Jurnal Perencanaan Pembangunan: The Indonesian Journal of Development Planning, 4(2), 240-252. https://doi.org/10.36574/jpp.v4i2.118.

Pradana, A. A., Casman, \& Nur'aini. (2020). Pengaruh Kebijakan Social Distancing pada Wabah COVID-19 terhadap Kelompok Rentan di Indonesia. Jurnal Kebijakan Kesehatan Indonesia, 09(2), 61-67.

Prihatiningsih, W. (2017). Motif Penggunaan Media Sosial Instagram di Kalangan Remaja. Communication, 8(1), 51. https://doi.org/10.36080/comm.v8i1.651.

Sari, D. P., Sholihah, N., \& Atiqoh. (2020). Hubungan antara Pengetahuan Masyarakat dengan Kepatuhan Penggunaan Masker sebagai Upaya Pencegahan Penyakit COVID-19 di Ngronggah. INFOKES Journal, 10(1), 52-55. Retrieved from http://ojs.udb.ac.id/index.php/infokes/article/view/850.

Utami, R. A., Mose, R. E., \& Martini, M. (2020). Pengetahuan, Sikap dan Keterampilan Masyarakat 
Herbawani, dkk - Pemanfaatan Instagram Live sebagai Sarana Edukasi ...

dalam Pencegahan COVID-19 di DKI Jakarta. Jurnal Kesehatan Holistic, 4(2), 68-77. https://doi. org/10.33377/jkh.v4i2.85.

WHO. (2020). Brazil: WHO Coronavirus Disease (COVID-19) Dashboard | WHO Coronavirus Disease (COVID-19) Dashboard. WHO. Retrieved from https://covid19.who.int/?gclid=Cj0KCQjwjer4B RCZARIsABK4QeU0FrvzuF-h2mKCUvm87kFcy4bsmwMagbdvlsUJqY8Db9tAEbuo1REaAgpBEA Lw_wcB

WHO. (2020). Situation Report-49 Situation in Numbers Total and New Cases in Last 24 Hours.

Yulia, I. (2018). Optimalisasi Penggunaan Media Sosial dalam Pemasaran Sosial dan Komunikasi Perubahan Perilaku (Suatu Pendekatan Studi Literature Review). HEARTY Jurnal Kesehatan Masyarakat, 6(2). https://doi.org/10.32832/hearty.v6i2.1276.

\section{Lampiran}

\section{List Pertanyaan}

Soal Pilihan Ganda

1. Sejarah New Normal

2. Keberhasilan New Normal

3. Protokol Keshetan di era New Normal

4. Peran mahasiswa di masa Pandemi COVID-19

5. Awal "New Normal" di masa Pandemi COVID-19

6. Syarat WHO terkait "New Normal"

7. Kegiatan berisiko tinggi saat Pandemi COVID-19

\section{Soal pilihan salah atau benar}

1. Penggunaan face shield sudah cukup dan tidak perlu menggunakan masker lagi.

2. Salah satu syarat New Normal yang dikeluarkan WHO adalah risiko kasus import dapat dikelola.

3. Penerapan New Normal di Indonesia sudah sesuai dengan persyaratan menurut WHO.

4. Grafik kasus COVID-19 menunjukkan penurunan merupakan syarat penerapan new normal dari WHO.

5. Penerapan lockdown secara terus menerus berisiko menyebabkan masyarakat mengalami gangguan psikososial.

6. Dari sisi epidemiologi, Kesehatan Masyarakat berperan menyajikan data terkait COVID-19.

7. Pergi dan berbelanja di mal termasuk kedalam kategori kegiatan yang berisiko rendah untuk dilakukan saat pandemi COVID-19 